\title{
Kennedy disease
}

INSERM

\section{Source}

INSERM. (1999). Orphanet: an online rare disease and orphan drug data base. Kennedy disease. ORPHA:481

Kennedy's disease, also known as bulbospinal muscular atrophy (BSMA), is a rare X-linked recessive motor neuron disease characterized by proximal and bulbar muscle wasting. 